\title{
Relationship of Breast Cancer Susceptibility with rs6257 and rs6258 Polymorphisms in the $S H B G$ Gene
}

\author{
Sara Shirzad ${ }^{1}$, Zahra Tahmasebi Fard ${ }^{2}$ and Seyed Hamid Jamaldini ${ }^{1,3,{ }^{*}}$ \\ ${ }^{1}$ Department of Genetics, Faculty of Advanced Science and Technology, Tehran Medical Sciences, Islamic Azad University, Tehran, Iran \\ 2 Department of biology, Roudehen Branch, Islamic Azad University, Roudehen, Iran \\ ${ }^{3}$ Medical Genomics Research Center, Tehran Medical Sciences, Islamic Azad University, Tehran, Iran
}

* Corresponding author: Seyed Hamid Jamaldini, Medical Genomics Research Center, Tehran Medical Sciences, Islamic Azad University, Tehran, Iran. Tel: +982122008065; Email: Jamaldini@iautmu.ac.ir \& Hjam1358@yahoo.co.uk

Received 2020 August 01; Revised 2020 September 18; Accepted 2020 0ctober 09.

\begin{abstract}
Background: Breast cancer is a hormone-dependent malignancy. Sex hormone-binding globulin (SHBG) is the main transport binding protein for sex steroid hormones in plasma and regulates their accessibility to target cells.

Objectives: The present study aimed to assess the relationship of breast cancer risk with rs6257 and rs6258 polymorphisms in the $S H B G$ gene.

Methods: This case-control study was conducted on 100 breast cancer patients and 100 healthy control subjects. After extracting DNA from peripheral blood, Genotyping was performed using the polymerase chain reaction-restriction fragment length polymorphism method. The data were analyzed in SPSS software using the chi-square test and logistic regression to distinguish the difference between the cases and controls in terms of the distribution of allele types and genotypes.

Results: The frequencies of Rs6257 were 78\%, 17\%, 5\% in the case group and 88\%, 7\%, and 5\% in control groups for TT, CC, and CT genotypes respectively. The rs6257 CC genotype showed about a 2.721-fold increase in breast cancer (P=0.030, 0R:2.721, CI95\%:1.0756.887). This genotype was reversely associated with age, body mass index, menopausal status, and breast cancer. Nonetheless, Rs6258 had no significant correlation with breast cancer risk or other demographic factors.

Conclusion: As evidenced by the obtained results, the rs6257 polymorphism may be a useful biomarker associated with breast cancer risk in Iranian women. To confirm the findings of the present study, larger studies are needed in the future.

Keywords: Breast cancer, Single nucleotide polymorphism, Sex hormone-binding globulin (SHBG)
\end{abstract}

\section{Background}

Breast cancer is the most common malignancy in women across the globe with a higher prevalence in developed countries (1). Some of the known etiologies of breast cancer risk are as follows: early menarche, nulliparity, late menopause, use of estrogen plus progestin hormone replacement therapy, high body mass index (BMI) among postmenopausal women (2), genetic, lifestyle, and environmental factors. Some complicated interactions may possibly mediate the familial risks. Furthermore, more complicated associated risks can be identified with the help of gene-gene or gene-environment interactions (3). Epidemiological evidence points to the critical role of sex hormones in breast cancer development (2). The estradiol and other lipophilic hormones circulate in the bloodstream while they are bound to sex hormonebinding globulin (SHBG)(4).

This gene of $3.2 \mathrm{~kb}$ size which is located on the short arm of chromosome17 (17p13-1p12) is composed of eight exons and seven introns $(5,6)$. The $S H B G$ synthesis is performed by the liver and controlled by nutritional factors and hormones (7). Sex steroids are regulated and transported to their target tissues by this plasma glycoprotein that binds to active androgens and estrogens in the bloodstream $(8,9)$. The most important biological form of this hormone is its free fraction. The free part of the hormone is generally a biologically essential form which is set with the unique property of $S H B G$. This fraction establishes cross-linking with estradiol pathways by inhibiting the growth and proliferation of estradiol-induced breast cancer cells (10). Therefore, estradiol bioavailability and cellular effects may be affected by SHBG levels (4). Some of the factors which modulate SHBG levels include body weight(4), pregnancy, exogenous sex steroids, as well as nutritional and metabolic status (8).

It has been demonstrated that sex hormone levels are associated with genetic variants of hormonerelated genes (2). Nonetheless, contradictory results have been reported on these associations and breast cancer risk $(3,11)$. Several studies pointed to the effect of common genetic variations of the $S H B G$ gene on the levels of this gene and its association with breast cancer, especially in postmenopausal women $(4,12,13)$. Multiple trials revealed a possible relationship between SHBG concentrations and breast cancer risk among different ethnic groups $(14,15)$.

\section{Objectives}

The present study aimed to assess the relationship between rs6257 and rs6258 polymorphisms in the $S H B G$ gene with breast cancer risk. 


\section{Methods}

\subsection{Study population}

This case-control study was conducted on women with breast cancer referring to Tajrish Shohada Hospital $(n=100)$ and healthy women within the age range of 41-75 years. The cases with breast cancer were diagnosed by pathologists based on clinical examinations, mammography, and clinical-pathological examination. For the purpose of the study, we collected participants' demographic characteristics, including age, menopausal status, $\mathrm{BMI}$, and previous cancer diagnosis.

\subsection{Inclusion and exclusion criteria}

The clinical information was retrieved from medical records, such as grade and the type of breast cancer cases. The healthy women were selected from cohort members who had no particular disease (e.g., cardiovascular disease, diabetes, and cancer), did not use any specific drug, and had no genetic background of breast cancer. The samples in both groups were either premenopausal or postmenopausal.

\subsection{Ethical considerations}

The study protocol is in line with the ethical guidelines of the 1975 Declaration of Helsinki as reflected in a prior approval by the Islamic Azad University of Tehran Medical Sciences Branch (Ethics Code: IR.IAU.TMU.REC.1396.206). Informed written consent was obtained from all participants that attended the project.

\subsection{Genotyping}

Genomic DNA was extracted from $5 \mathrm{ml}$ peripheral blood of all subjects using the salting-out method (16), and its purity and quality were confirmed using NanoDrop (Thermo Scientific, Wilmington, NC) and agarose gel.

Specific primers were used for amplifying the Rs6257 polymorphism by forward primer sequences 5'-TTCTCTCCTCTGGCCCTGTA-3' and reveres primer 5'-TAGGCCAACCCCATACTTTG-3 and Rs6258 polymorphism of SHBG using the forward primer 5'AGTCAAGATGGAGGGGGACT-3' and reveres primer 5'- ACCCAGCAGTGCTTTACCAA-3'. For every polymerase chain reaction (PCR), $10 \mu \mathrm{l}$ water, $10 \mu \mathrm{l}$ of the master mix $2 \mathrm{X}, 1 \mu \mathrm{l}$ of each primer, and $1 \mu \mathrm{l}$ (100ng) from genomic DNA of each sample were added, mixed, and placed in a thermocycler (Eppendorf Master Cycler gradient, Germany). PCR program for rs6257and rs6258 consisted of an initial denaturation at $95^{\circ} \mathrm{C}$ for $5 \mathrm{~min}$, followed by 37 cycles of $95^{\circ} \mathrm{C}$ for $60 \mathrm{sec}, 60^{\circ} \mathrm{C}$ for $30 \mathrm{sec}, 75^{\circ} \mathrm{C}$ for $40 \mathrm{sec}$, and one cycle of $72^{\circ} \mathrm{C}$ for $7 \mathrm{~min}$. The proliferated products were loaded on a $1.5 \%$ agarose gel associated with DNA Safe6x, along with a $100 \mathrm{bp}$ size marker, at a fixed voltage of $100 \mathrm{v}$ for 30-40 min, and 198bp and 213bp bands were detected for
Rs6257 and Rs6258, respectively, according to the marker size.

The digestion of PCR products was performed with 5 units of ACiI and MspI restriction enzyme at $37^{\circ} \mathrm{C}$ for $16-18 \mathrm{~h}$, and the $3 \%$ agarose gel electrophoresis was used for the separation of the digested products. The resulting fragments for Rs6257were as follows: 74bp, 124bp, 198bp bands for the heterozygote genotype (TC/CT), $124 \mathrm{bp}$ and $74 \mathrm{bp}$ bands for the homozygote mutant genotype CC, and 198bp band for the Wild-type homozygote genotype (TT). On the other hand, for Rs6258, the results were as follows: $58 \mathrm{bp}, 155 \mathrm{bp}$, and $213 \mathrm{bp}$ bands for the heterozygote genotype (TC/CT), $155 \mathrm{bp}$ and 58bp bands for the mutant homozygote genotype (TT), and only one $213 \mathrm{bp}$ band for the Wild-type homozygote (CC).

\subsection{Statistical Analysis}

The allele and genotype frequency in both groups was achieved according to Hardy-Weinberg equilibrium. The data regarding the relationship between genotypes and the risk of breast cancer in two groups were analyzed in SPSS software (version 23) using the chi-square test and logistic regression analysis to obtain the crude and adjusted odds ratios (ORs) of polymorphisms at a significance level of $\mathrm{P}<0.05$. The participants in the two groups were assigned to two subgroups based on BMI (BMI $\geq 25$ and BMI $<25)$ and age $(<50$ and $\geq 50$ years $)$ to study the relationship between polymorphism genotypes and breast cancer risk. The mean serum levels of age and BMI were also calculated in the case and control groups using unpaired t-test and were reported as Mean \pm SD.

\section{Results}

The participants in the case and control groups were within the age range of 41-75 years, with mean age scores of $61 \pm 8.58$ and $55.7 \pm 8.40$ years, respectively $(\mathrm{P}=3 \times 10-6)$. The mean $\mathrm{BMI}$ scores were reported as $25.77 \pm 2.87$ and $24.04 \pm 2.15$ in the case and control groups, respectively. The characteristics of case and control groups are presented in Table 1.

According to the Hardy-Weinberg principle for Rs6257, the homozygous TT genotype was detected in $78(78 \%)$ and $88(88 \%)$ patients in the case and control groups, respectively, ( $\mathrm{P}=0.060$, OR: 0.483 CI95\%:0.225$1.04)$. The CC genotype was observed in $17(17 \%)$ and $7(7 \%)$ cases in the case and control groups, respectively ( $\mathrm{P}=0.030$, OR: 2.721 , CI95\%: 1.075-6.887). The GT/TG genotype was detected in $5(5 \%)$ patients in the case group and $5(5 \%)$ subjects in the control group $(\mathrm{P}=1$, OR: 1, CI95\%: 0.280-3.567). A 2.721-fold increased risk of breast cancer was detected among people with homozygous mutant CC genotype.

The $\mathrm{T}$ allele frequency was reported as $80.5 \%$ and $90.5 \%$ in the case and control groups, respectively. Moreover, the frequency of the C allele was $19.5 \%$ in 
the cancer group and $9.5 \%$ in the control group ( $\mathrm{P}=0.005$, OR: 2.308, CI95\%: 1.282-4.155). Table 2 displays the association between Rs 6257 genotypes and demographic factors to understand the effect of Rs6257 on breast cancer. The homozygous mutant CC genotype was significantly associated with age (P=0.050, OR: 0.390, CI95\%: 0.153-0.999) and BMI (P=0.040, OR: 0.351 CI95\%: 0.129-0.955).

The Rs 6258 genotypes were analyzed in case and control groups. As presented, the genotypes in the case and control groups were as follows: the CC genotype among 84(84\%) breast cancer cases and $90(90 \%)$ controls ( $\mathrm{P}=0.207$, OR: 0.583, CI95\%: 0.2511.357), the TT mutant genotype among $10(10 \%)$ cases and 5(5\%) controls ( $\mathrm{P}=0.179, \mathrm{OR}: 2.111, \mathrm{CI} 95 \%$ : 0.695-6.416), and CT genotype among 6(6\%) cases and $5(5 \%)$ controls $(\mathrm{P}=0.756, \mathrm{OR}: 1.213, \mathrm{CI} 95 \%$ : 0.358-4.110).

Based on the results, the $\mathrm{C}$ allele (87\%) and $\mathrm{T}$ allele $(13 \%)$ had the highest and lowest prevalence among cancer patients. On the other hand, in the control group, the highest and lowest prevalence rates were related to the $\mathrm{C}$ allele $(92.5 \%)$ and $\mathrm{T}$ allele (7.5\%) ( $\mathrm{P}=0.070$, OR: 0.543, CI95\%: 0.278-1.059).

The relationship between demographic factors (e.g., age, BMI, and menopausal status) and Rs 6257 polymorphism in the case and control groups is demonstrated in Table 3; nonetheless, none of them

\begin{tabular}{|c|c|c|c|c|}
\hline Characteristics & & Case & Control & P-Value \\
\hline \multirow{3}{*}{ Age } & $50 \geq$ & 16 & 29 & \\
\hline & $50<$ & 84 & 71 & \\
\hline & Mean \pm SD & $61 \pm 8.58$ & $55.7 \pm 8,40$ & $1.7 \times 10^{-5}$ \\
\hline \multirow{3}{*}{ Body mass index } & $25 \geq$ & 37 & 76 & \\
\hline & $25<$ & 63 & 24 & \\
\hline & Mean \pm SD & $25.77 \pm 2.87$ & $24.04 \pm 2.15$ & $3 \times 10^{-6}$ \\
\hline \multirow{2}{*}{ Menopausal Status } & Pre-Menopausal & 33 & 59 & \\
\hline & Post-Menopausal & 67 & 41 & $2.25 \times 10^{-4}$ \\
\hline \multirow{4}{*}{ Type of cancer } & ILC & 34 & & \\
\hline & IDC & 40 & & \\
\hline & DCIS & 18 & & \\
\hline & LCIS & 8 & & \\
\hline \multirow{4}{*}{ Grade } & I & 20 & & \\
\hline & II & 24 & & \\
\hline & III & 41 & & \\
\hline & IV & 15 & & \\
\hline
\end{tabular}

\begin{tabular}{|c|c|c|c|c|c|c|c|}
\hline & & \multicolumn{6}{|c|}{ Rs 6257} \\
\hline & & \multicolumn{2}{|c|}{ TT } & \multicolumn{2}{|c|}{ CC } & \multicolumn{2}{|c|}{ CT } \\
\hline & & Case & Control & Case & Control & Case & Control \\
\hline \multirow{4}{*}{ Age } & $50 \geq$ & 13 & 27 & 3 & 0 & 0 & 2 \\
\hline & $50<$ & 65 & 61 & 14 & 7 & 5 & 3 \\
\hline & P-Value & \multirow{2}{*}{\multicolumn{2}{|c|}{$\begin{array}{c}1 \\
\text { Referent }\end{array}$}} & \multirow{2}{*}{\multicolumn{2}{|c|}{$\begin{array}{c}0.50 \\
0.390(0.153-0.999)\end{array}$}} & \multirow{2}{*}{\multicolumn{2}{|c|}{$\begin{array}{c}0.886 \\
0.910(0.251-3.304)\end{array}$}} \\
\hline & OR (CI95\%) & & & & & & \\
\hline \multirow{4}{*}{$\begin{array}{l}\text { Body mass } \\
\text { index }\end{array}$} & $25 \geq$ & 27 & 68 & 8 & 4 & 2 & 4 \\
\hline & $25<$ & 51 & 20 & 9 & 3 & 3 & 1 \\
\hline & P-Value & \multirow{2}{*}{\multicolumn{2}{|c|}{$\begin{array}{c}1 \\
\text { Referent }\end{array}$}} & \multirow{2}{*}{\multicolumn{2}{|c|}{$\begin{array}{c}0.040 \\
0.351(0.129-0.955)\end{array}$}} & \multirow{2}{*}{\multicolumn{2}{|c|}{$\begin{array}{c}0.783 \\
0.823(0.206-3.292)\end{array}$}} \\
\hline & OR (CI95\%) & & & & & & \\
\hline \multirow{4}{*}{$\begin{array}{l}\text { Menopausal } \\
\text { status }\end{array}$} & Pre-Menopausal & 25 & 55 & 7 & 2 & 1 & 2 \\
\hline & Post-Menopausal & 53 & 33 & 10 & 5 & 4 & 3 \\
\hline & P-Value & \multirow{2}{*}{\multicolumn{2}{|c|}{$\begin{array}{c}1 \\
\text { Referent }\end{array}$}} & \multirow{2}{*}{\multicolumn{2}{|c|}{$\begin{array}{c}0.049 \\
0.384(0.147-1.003)\end{array}$}} & \multirow{2}{*}{\multicolumn{2}{|c|}{$\begin{array}{c}0.916 \\
1.073(0.287-4.011)\end{array}$}} \\
\hline & OR (CI95\%) & & & & & & \\
\hline , & (a) & \multicolumn{6}{|c|}{ Rs 6258} \\
\hline & & \multicolumn{2}{|c|}{$\mathrm{CC}$} & \multicolumn{2}{|c|}{ TT } & \multicolumn{2}{|c|}{ CT } \\
\hline & & Case & Control & Case & Control & Case & Control \\
\hline \multirow{4}{*}{ Age } & $50 \geq$ & 14 & 26 & 1 & 2 & 1 & 1 \\
\hline & $50<$ & 70 & 64 & 9 & 3 & 5 & 4 \\
\hline & P-Value & \multirow{2}{*}{\multicolumn{2}{|c|}{$\begin{array}{c}1 \\
\text { Referent }\end{array}$}} & \multirow{2}{*}{\multicolumn{2}{|c|}{$\begin{array}{c}0.188 \\
0.469(0.152-1.447)\end{array}$}} & \multirow{2}{*}{\multicolumn{2}{|c|}{$\begin{array}{c}0.722 \\
0.802(0.233-2.763)\end{array}$}} \\
\hline & OR (CI95\%) & & & & & & \\
\hline \multirow{4}{*}{$\begin{array}{l}\text { Body mass } \\
\text { index }\end{array}$} & $25 \geq$ & 31 & 70 & 4 & 3 & 2 & 3 \\
\hline & $25<$ & 53 & 20 & 3 & 2 & 4 & 2 \\
\hline & P-Value & \multirow{2}{*}{\multicolumn{2}{|c|}{$\begin{array}{c}1 \\
\text { Referent }\end{array}$}} & \multirow{2}{*}{\multicolumn{2}{|c|}{$\begin{array}{c}0.264 \\
0.504(0.152-1.676)\end{array}$}} & \multirow{2}{*}{\multicolumn{2}{|c|}{$\begin{array}{c}0.928 \\
0.940(0.248-3.567)\end{array}$}} \\
\hline & OR (CI95\%) & & & & & & \\
\hline \multirow{4}{*}{$\begin{array}{l}\text { Menopausal } \\
\text { status }\end{array}$} & Pre-Menopausal & 28 & 54 & 3 & 7 & 2 & 4 \\
\hline & Post-Menopausal & 56 & 36 & 3 & 2 & 2 & 3 \\
\hline & P-Value & & 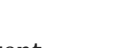 & & 10 & & \\
\hline & OR (CI95\%) & & ent & 0.479 & 52-1.514) & 0.862 & $3-3.054)$ \\
\hline
\end{tabular}




\begin{tabular}{|c|c|c|c|c|c|c|c|}
\hline & \multirow[b]{2}{*}{ Genotype } & \multicolumn{3}{|c|}{ Type Cancer } & \multicolumn{3}{|r|}{ Grade } \\
\hline & & In Situ & Invasive & $\begin{array}{c}\text { P-Value } \\
\text { OR (CI95\%) }\end{array}$ & I/II & III-V & $\begin{array}{c}\text { P-Value } \\
\text { OR (CI95\%) } \\
\end{array}$ \\
\hline \multirow{3}{*}{$\begin{array}{l}\text { RS } \\
6257\end{array}$} & TT & 21 & 57 & $\begin{array}{c}1 \\
\text { Referent }\end{array}$ & 27 & 51 & $\begin{array}{c}1 \\
\text { Referent }\end{array}$ \\
\hline & $\mathrm{CC}$ & 3 & 14 & $\begin{array}{c}0.429 \\
0.582(0.152-2.229)\end{array}$ & 5 & 12 & $\begin{array}{c}0.681 \\
0.787(0.251-2.468)\end{array}$ \\
\hline & CT & 2 & 3 & $\begin{array}{c}0.532 \\
1.081(0.282-11.599)\end{array}$ & 2 & 3 & $\begin{array}{c}0.807 \\
1.259(0.198-8.001)\end{array}$ \\
\hline \multirow{3}{*}{$\begin{array}{l}\text { RS } \\
6258\end{array}$} & $\mathrm{CC}$ & 21 & 63 & $\begin{array}{c}1 \\
\text { Referent }\end{array}$ & 27 & 57 & $\begin{array}{c}1 \\
\text { Referent }\end{array}$ \\
\hline & TT & 3 & 7 & $\begin{array}{c}0.732 \\
1.286(0.305-5.426)\end{array}$ & 5 & 5 & $\begin{array}{c}0.268 \\
2.11(0.563-7.914)\end{array}$ \\
\hline & CT & 2 & 4 & $\begin{array}{c}0.653 \\
1.500(0.256-8.787) \\
\end{array}$ & 2 & 4 & $\begin{array}{c}0.952 \\
1.056(0.182-6.123)\end{array}$ \\
\hline
\end{tabular}

\begin{tabular}{lcccc}
\hline \multicolumn{1}{l}{ Table 5. Combined effect of both Rs6257 and Rs6258 polymorphism in case and control groups } \\
\hline Genotype & Cases & Controls & P-value & OR CI95\% \\
\hline TT/CC & 68 & 81 & 0.035 & $0.498(0.259-0.957)$ \\
CC/CC & 12 & 6 & 0.138 & $2.136(0.769-5.938)$ \\
CT/CC & 5 & 7 & 0.552 & $0.699(0.214-2.282)$ \\
TT/TT & 6 & 4 & 0.516 & $1.532(0.419-5.603)$ \\
CC/TT & 4 & 1 & 0.174 & $4.125(0.453-37.573)$ \\
CT/TT & 0 & 0 & - & - \\
TT/CT & 5 & 3 & 0.470 & $1.702(0.396-7.321)$ \\
CC/CT & 1 & 2 & 0.561 & $0.495(0.044-5.548)$ \\
CT/CT & 0 & 2 & 0.155 & $1.020(0.992-1.049)$ \\
\hline
\end{tabular}

showed a statistically significant correlation with genotypes.

Furthermore, we analyzed the effects of the two polymorphisms of the SHBG gene (rs6257 and Rs6258) on the type and grade of cancer. The obtained results did not show a significant relationship between genotypes and clinicopathology of disease in case groups. The results are displayed in Table 4.

In the current study, we analyzed the combined effect of both Rs6257and Rs6258 polymorphism on breast cancer. It was found that TT/CC compound genotypes had a statistically significant relationship with breast cancer and was associated with a 0.498 decreased risk of developing breast cancer. Data is presented in Table 5.

\section{Discussion}

The risk of developing breast cancer risk is associated with multiple reproductive and hormonal factors (17). In this regard, SHBG which functions as a segment in the novel steroid signaling pathway (18) exerts an effect on some genes involved in Estrogendependent cell signaling, proliferation, and apoptosis (19). The interaction of SHBG with breast cells leads to the activation of a specific pathway, which in turn, results in cross-talk between this pathway and the estradiol-activated pathway (10). Therefore, it is highly correlated with estrogen-sensitivity and cell proliferation (19).

In the present study, the case and control groups were matched for age and BMI, and the frequency of postmenopausal women was higher in the case group. We analyzed the association between rs6257and re6258 polymorphisms and the risk of breast cancer. A higher correlation was observed between rs6257polymorphism and breast cancer. The C allele of rs6257 homozygotes genotype (CC) was associated with a 2.308 fold increased risk of breast cancer, compared to $\mathrm{T}$ allele carriers.

Along the same lines, Thompson DJ et al. suggested that rs6257 is a potential factor for breast cancer susceptibility (12). Riancho JA et al. reported that the C/T rs6257 polymorphism is situated in an intronic region (intron1) and was correlated with the levels of SHBG among postmenopausal women; nonetheless, the mechanism is unclear. It probably is placed in a potential binding site for Foxa or hepatic nuclear factor 3 (HNF-3) transcription factors (4). When the results of rs6257 genotypes were adjusted for age, BMI, and menopausal status, simply CC mutant homozygote genotype demonstrated 0.390 , 0.35 , and 0.384 folds decreased risk of breast cancer, respectively.

The obtained results showed no significant correlation between rs6258 and breast cancer risk. The univariate regression analysis did not link breast cancer to menopausal status, body weight, age, and rs6258 polymorphisms. So far, no study has been conducted on the association between this Single nucleotide polymorphism and breast cancer risk. Freedman ND et al. examined the relationship between Rs 6258 and gastric cancer risk; however, no statistically significant associations were observed (20). In the present research, the TT/CC compound 
genotypes of rs6257 and rs 6258 were inversely correlated with the risk of breast cancer.

Zhou JY et al. conducted a large meta-analysis (which included 10,454 cases and 13,111 controls) on the relationship between SHBG Asp327Asn (rs6259) polymorphism and breast cancer risk. They did not observe any relationship between Asp327Asn polymorphism of SHBG and the risk of breast cancer, while it might be a key genetic factor involved in breast cancer risk among postmenopausal Asian women (21). In line with some previously conducted studies, an association was observed between $S H B G$ rs6257 and breast cancer risk. Other genetic variants in hormone-related genes may have also an effect on breast cancer susceptibility.

\section{Conclusion}

SHBG polymorphisms which affect the production or the metabolism of the protein represent the background genes involved in the action of sex steroid hormones in human beings. The existing heterogeneity in the relevant results of these studies indicates that various factors influence SHBG variation. SHBG polymorphisms seem to affect the development of breast cancer as genetic changes do. The discrepancy in the results can be attributed to different populations or various techniques which were used for the identification of polymorphism. To determine the validity of these findings, it is recommended to perform studies with larger sample sizes.

\section{Acknowledgements}

The authors' deepest appreciation goes to the medical personnel of Tajrish Shohada Hospital in Tehran and all the patients who participated in this study (Code of ethics: IR.IAU.TMU.REC.1396.206).

\section{Footnotes}

Conflict of Interests: The authors declare that they have no conflict of interest regarding the publication of the current article.

Funding/Support: The current study was financially supported by Sara Shirzad (Master of Science). This article was extracted from a master's thesis submitted by Seyed Hamid Jamaldini.

\section{References}

1. Ghoncheh M, Pournamdar Z, Salehiniya H. Incidence and mortality and epidemiology of breast cancer in the world. Asian Pac J Cancer Prev. 2016;17(S3):43-6. doi: 10.7314/apjcp.2016.17.s3.43. [PubMed: 27165206].

2. Clendenen T, Zeleniuch-Jacquotte A, Wirgin I, Koenig KL, Afanasyeva Y, Lundin E, et al. Genetic variants in hormonerelated genes and risk of breast cancer. PLoS One. 2013; 8(7):e69367. doi: 10.1371/journal.pone.0069367. [PubMed: 23935996].
3. Mavaddat N, Antoniou AC, Easton DF, Garcia-Closas M. Genetic susceptibility to breast cancer. Mol Oncol. 2010;4(3):174-91. doi: 10.1016/j.molonc.2010.04.011. [PubMed: 20542480].

4. Riancho JA, Valero C, Zarrabeitia MT, Garcia-Unzueta MT, Amado JA, Gonzalez-Macias J. Genetic polymorphisms are associated with serum levels of sex hormone binding globulin in postmenopausal women. BMC Med Genet. 2008;9:112. doi: 10.1186/1471-2350-9-112. [PubMed: 19091090].

5. Kahn SM, Hryb DJ, Nakhla AM, Romas NA, Rosner W. Beyond carrier proteins: sex hormone-binding globulin is synthesized in target cells. J Endocrinol. 2002;175:113-20.

6. Berube D, Seralini GE, Gagne R, Hammond GL. Localization of the human sex hormone-binding globulin gene (SHBG) to the short arm of chromosome 17 (17p12----p13). Cytogenet Cell Genet. 1990;54(1-2):65-7. doi: 10.1159/000132958. [PubMed: 2249477].

7. Pugeat M, Nader N, Hogeveen K, Raverot G, Déchaud H, Grenot C. Sex hormone-binding globulin gene expression in the liver: drugs and the metabolic syndrome. Mol Cell Endocrinol. 2010;316(1):53-9. doi: 10.1016/j.mce.2009.09.020. [PubMed: 19786070].

8. Eriksson AL, Lorentzon M, Mellstrom D, Vandenput L, Swanson C, Andersson N, et al. SHBG gene promoter polymorphisms in men are associated with serum sex hormone-binding globulin, androgen and androgen metabolite levels, and hip bone mineral density. J Clin Endocrinol Metab. 2006;91(12):5029-37. doi: 10.1210/jc.2006-0679. [PubMed: 16926255].

9. Hammond GL. Molecular properties of corticosteroid binding globulin and the sex-steroid binding proteins. Endocr Rev. 1990;11(1):65-79. doi: 10.1210/edrv-11-1-65. [PubMed: 2180688].

10. Fortunati N, Catalano MG, Boccuzzi G, Frairia R. Sex hormonebinding globulin (SHBG), estradiol and breast cancer. Mol Cell Endocrinol. 2010;316(1):86-92. doi: 10.1016/j.mce.2009.09.012. [PubMed: 19770023].

11. Breast Cancer Association Consortium. Commonly studied single-nucleotide polymorphisms and breast cancer: results from the Breast Cancer Association Consortium. J Natl Cancer Inst. 2006;98(19):1382-96. doi: 10.1093/jnci/djj374. [PubMed: 17018785].

12. Thompson DJ, Healey CS, Baynes C, Kalmyrzaev B, Ahmed S, Dowsett $M$, et al. Identification of common variants in the SHBG gene affecting sex hormone binding globulin levels and breast cancer risk in postmenopausal women. Cancer Epidemiol Biomarkers Prev. 2008;17(12):3490-8. doi: 10.1158/1055-9965.EPI-08-0734. [PubMed: 19064566].

13. Xita N, Tsatsoulis A. Genetic variants of sex hormone-binding globulin and their biological consequences. Mol Cell Endocrinol. 2010;316(1):60-5. doi: 10.1016/j.mce.2009.08.025. [PubMed: 19733622].

14. Shulman LN, Willett W, Sievers A, Knaul FM. Breast cancer in developing countries: opportunities for improved survival. J Oncol. 2010;2010:595167. doi: 10.1155/2010/595167. [PubMed: 21253541].

15. Quan L, Hong CC, Zirpoli G, Roberts MR, Khoury T, SuchestonCampbell LE, et al. Variants of estrogen-related genes and breast cancer risk in European and African American women. Endocr Relat Cancer. 2014;21(6):853-64. doi: 10.1530/ERC14-0250. [PubMed: 25228414].

16. Noguera NI, Tallano CE, Bragos IM, Milani AC. Modified saltingout method for DNA isolation from newborn cord blood nucleated cells. J Clin Lab Anal. 2000;14(6):280-3. doi: 10.1002/1098-2825(20001212)14:6\&\#x0003c;280::AIDJCLA6\&\#x0003e;3.0.C0;2-0. [PubMed: 11138610].

17. Key TJ. Endogenous oestrogens and breast cancer risk in premenopausal and postmenopausal women. Steroids. 2011; 76(8):812-5. doi: 10.1016/j.steroids.2011.02.029. [PubMed: 21477610].

18. Fortunati N, Catalano MG. Sex hormone-binding globulin (SHBG) and estradiol cross-talk in breast cancer cells. Horm Metab Res. 2006;38(4):236-40. doi: 10.1055/s-2006-925337. [PubMed: 16700004].

19. Catalano MG, Costantino L, Frairia R, Boccuzzi G, Fortunati N. Sex hormone-binding globulin selectively modulates 
estradiol-regulated genes in MCF-7 cells. Horm Metab Res. 2007;39(4):288-94. doi: 10.1055/s-2007-973814. [PubMed: 17447168].

20. Freedman ND, Ahn J, Hou L, Lissowska J, Zatonski W, Yeager M, et al. Polymorphisms in estrogen- and androgen-metabolizing genes and the risk of gastric cancer. Carcinogenesis. 2009;30(1):71-7. doi: 10.1093/carcin/bgn258. [PubMed:
19015200].

21. Zhou JY, Shi R, Yu HL, Zheng WL, Ma WL. Association between SHBG Asp327Asn (rs6259) polymorphism and breast cancer risk: a meta-analysis of 10,454 cases and 13,111 controls. Mol Biol Rep. 2012;39(8):8307-14. doi: 10.1007/s11033-0121680-2. [PubMed: 22711300]. 